\title{
Semi-Empirical Model for Predicting the Swelling Stress of Compacted, Unsaturated Expansive Soils
}

\author{
Armand Augustin Fondjo ${ }^{1, *}$, Elizabeth Theron $^{1}$, Richard P. Ray ${ }^{2}$ \\ ${ }^{1}$ Department of Civil Engineering, Central University of Technology, South Africa \\ ${ }^{2}$ Department of Structural and Geotechnical Engineering, Széchenyi István Egyetem University, Hungary
}

Received October 1, 2020; Revised November 11, 2020; Accepted December 6, 2020

\section{Cite This Paper in the following Citation Styles}

(a): [1] Armand Augustin Fondjo, Elizabeth Theron, Richard P. Ray, "Semi-Empirical Model for Predicting the Swelling Stress of Compacted, Unsaturated Expansive Soils," Civil Engineering and Architecture, Vol. 9, No. 1, pp. 225 239, 2021. DOI: 10.13189/cea.2021.090119.

(b): Armand Augustin Fondjo, Elizabeth Theron, Richard P. Ray (2021). Semi-Empirical Model for Predicting the Swelling Stress of Compacted, Unsaturated Expansive Soils. Civil Engineering and Architecture, 9(1), 225 - 239. DOI: 10.13189/cea.2021.090119.

Copyright $\bigcirc 2021$ by authors, all rights reserved. Authors agree that this article remains permanently open access under the terms of the Creative Commons Attribution License 4.0 International License

\begin{abstract}
Heaving soils are the most problematic worldwide. These soils develop swelling stress that produces uplift forces detrimental to the foundations. In engineering practice, swelling stress is not considered in general. Considering the swelling stress in foundation design enhances the service life of construction. The oedometer swelling test is the technique ordinarily used to assess the swelling stress. Nonetheless, the oedometer swelling test is cumbersome, time-consuming, making the test unattractive, and not cost-effective for the low-cost housing project. The objective of this research work is to propose a model to predict swelling stress as an alternative to oedometer testing. Geotechnical studies such as Atterberg limits, particle size distribution, free swell ratio, specific gravity, linear shrinkage, suction measurement, Proctor compaction test, and zero-swell test are performed to estimate the soil properties. Multivariate regression analysis is performed using NCSS.11 Program to develop the predictive model. The model is assessed base on the following: determining coefficient value, comparing predicted values with experimental values, comparing the proposed model with other existing models found in the literature. Besides, the Box-cox transformation function is used to improve the accuracy of the model. The developed model can be utilized to assess the swelling stress of compacted heaving soils, and it is much more accurate than other existing models.
\end{abstract}

Keywords Geotechnical Index Properties, Heaving Soils, Optimum Water Content, Soil Suction, Swelling Stress

\section{Introduction and Background}

Defects on constructions caused by heaving soils were first reported in South Africa in 1950, especially in Goldfield Mine Free State. In South Africa, heaving soils are considered the most problematic [1]. The repair cost of damages induced by heaving soils in South Africa is around R100 million yearly [1]. The expense of defects in the UK is estimated at $£ 400$ million every year [2]. Heaving soils cause a higher yearly financial loss than the hurricane, flood, earthquake, and tornadoes combined [3]. A good understanding of the hydro-mechanical properties of heaving soils is imperative to enhance engineering design. The objective of this research work is to develop a model to predict the swelling stress of compacted heaving soils as an alternative to oedometer testing. Equations shown in Table 1 have been developed throughout the years to predict the swelling stress. Reference [4] attempted the utilization of soil suction to predict swelling stress using bentonite and kaolinite. The estimation of soil suction is performed using a thermocouple psychrometers technique on artificial compacted soil specimens. A standard swell volume experiment is performed on soil specimens. The proposed Equations (1) \& (2) are in Table 1. These models cannot predict a swelling stress value beyond $350 \mathrm{kPa}$. Reference [5] performed one-dimensional swell tests on heaving clay containing kaolinite, bentonite 
upon various plasticities. Then, soil specimens are compacted at different initial moisture content $\left(\mathrm{W}_{\mathrm{i}}\right)$ and dry unit weight $\left(\gamma_{d}\right)$. Model Equation (3) presented in Table 1 is developed without the soil suction using three independent variables as follows: Plasticity index, water content, and dry unit weight. Another research work conducted by [6] revealed that soil suction is a significant parameter in the prediction of swelling stress. Reference [7] studied the correlations swelling stress and index properties of heaving soils. Table 1 shows the proposed model Equation (4). This model was developed based on two independent variables, the activity of clay and initial water content. However, another research work by [8] revealed that the index properties such as the plasticity index, the activity of the clays could not accurately predict the swelling behavior of heaving soils because they do not consider the impact of the clay mineral. Besides, by the addition of the soil suction as an independent variable, the model efficiency enhances. Reference [9] conducted a series of oedometer tests on heaving soils to determine the swelling stress developed within the soil specimens upon the initial moisture content, dry unit weight, and swell-shrink index. Table 1 shows the proposed model Equation (5). Equation (5) does not consider the plasticity index and soil suction. Reference [7] pointed out that the augmentation of the plasticity index increases the swelling stress of heaving soils significantly.
However, according to the results of the study carried out by [8] on heaving soils. The swell/shrink index is not a good predictor of fine-grained soil swelling behaviour. That is because the clay mineral influences the swelling stress. Moreover, the soil shrinkage is governed by the packing phenomenon and influenced by the relative particle distribution size of fine-grained materials. Reference [10] developed a mathematical model to predict the swelling stress of heaving soils. The tested soil specimens comprise kaolinite and bentonite in various proportions. Model Equation (6) consists of three independent variables as follows: the activity of clay, dry unit weight, and initial water content. Besides, the model does not consider other relevant parameters like soil suction. Reference [6] proposed a model Equation (7) to predict the swelling stress for heaving compacted soil for soil suction utilizing the soil-water characteristic curve (SWCC). Furthermore, the SWCC gives the soil suction, degree of saturation, water content but not the maximum dry unit weight $\left(\gamma_{\mathrm{dmax}}\right)$ as used in Equation (7) or other relevant soil parameters that influence the swelling stress. Reference [11] investigated the swelling stress of heaving clay of Barranquilla, Colombia, and developed a semi-empirical model Equation (8) using the plasticity index (PI) and the water content (W).

Table 1. Models to predict swelling stress

\begin{tabular}{|c|c|c|}
\hline Source & Models & \\
\hline \multirow{6}{*}{ [4] } & $0<\mathrm{P}_{\mathrm{s}}<100 \mathrm{kPa}$ & \\
\hline & $\mathrm{P}_{\mathrm{s}}=-3.72+0.011 \times \mathrm{PI}+2.077 \times \gamma_{\mathrm{d}}+0.244 \times \log \left(\Psi_{\mathrm{m}}\right)$ & (1) \\
\hline & $\mathrm{R}^{2}=0.920$ & \\
\hline & $100 \mathrm{kPa}<\mathrm{Ps}<350 \mathrm{kPa}$ & \multirow{3}{*}{ (2) } \\
\hline & $\mathrm{P}_{\mathrm{s}}=-16.31+0.0330 \times \mathrm{PI}+8.253 \times \gamma_{\mathrm{d}}+0.829 \times \log \left(\Psi_{\mathrm{m}}\right)$ & \\
\hline & $\mathrm{R}^{2}=0.940$ & \\
\hline \multirow{2}{*}{ [5] } & $\log \left(P_{s}\right)=-5.423+0.0145 \times P I+2.563 \times \gamma_{d}-0.0168 \times W_{i}$ & \multirow[t]{2}{*}{$(3)$} \\
\hline & $\mathrm{R}^{2}=0.950$ & \\
\hline \multirow{2}{*}{ [7] } & $P_{s}=43.6 \times A_{c}+68 \times W_{i}-915$ & \multirow[t]{2}{*}{ (4) } \\
\hline & $\mathrm{R}^{2}=0.958$ & \\
\hline \multirow{2}{*}{ [9] } & $\log \left(P_{s}\right)=-0.284+0.0686 \times I_{s s}-0.185 \times \gamma_{d}-0.031 \times W_{i}$ & \multirow[t]{2}{*}{$(5)$} \\
\hline & $\mathrm{R}^{2}=0.940$ & \\
\hline \multirow{2}{*}[10]{} & $\log \left(P_{s}\right)=14.155+0.021 \times A_{c}-7.469 \times \gamma_{d}-0.063 \times W_{i}$ & \multirow[t]{2}{*}{ (6) } \\
\hline & $\mathrm{R}^{2}=0.975$ & \\
\hline \multirow{2}{*}{ [6] } & $\mathrm{P}_{\mathrm{s}}=55+\beta_{\mathrm{c}} \times \Psi_{\mathrm{m}} \times[\mathrm{S} / 100]^{2}$ & \multirow[t]{2}{*}{ (7) } \\
\hline & $\beta_{c}=(0.25 / 1000) \times \mathrm{e}^{5.306 \times \gamma_{\mathrm{dmax}}}$ & \\
\hline \multirow{2}{*}{ [11] } & $\ln \left(\mathrm{P}_{\mathrm{s}}\right)=7.77-0.12 \times \mathrm{W}_{\mathrm{i}}+0.0054 \times \mathrm{PI}$ & \multirow[t]{2}{*}{ (8) } \\
\hline & $\mathrm{R}^{2}=0.860$ & \\
\hline
\end{tabular}


Lightweight constructions are the most exposed structures experiencing severe damages when built on heaving soils. The swelling stress is not considered in engineering practice generally. Nonetheless, the swelling stress can generate important swelling stress (uplift forces) harmful to the stability of foundations. Reference [3] suggested the types of suitable foundations in heaving soils as follows: Pier and beam; pile and beam; reinforced rafts and modified continuous perimeter spread footing. Reference [12] recommended that the swelling stress should not exceed the calculated foundation pressure to avoid heave of foundation. Simultaneously, the foundation pressure should not exceed the bearing limit of the soil given by geotechnical studies to prevent foundation displacement. In general, few equation models for field compacted heaving soils are available. Because of the variability of soil material, models are developed for a specific location and type of soil material. The reviewed models consist of different numbers of soil parameters and various soil materials as independent variables. The type of soil material and the number of independent variables are unique for each model. Independent variables are classified as follows: unsaturated soil characteristics, geotechnical index properties, heaving soil indexes. To enhance the design of the foundation in heaving soils, an investigation of the correlation swelling stress and the soil properties is essential. Moreover, the development of a mathematical model to predict the swelling stress is fundamental.

\section{Materials and Testing Program}

Soil samples collection by digging out at $50 \mathrm{~cm}$ from the ground surface across the Free State province. Bloemfontein soils (BLS-A; BLS-B; BLS-C); Winburg soils (WBS-A; WBS-B; WBS-C); Welkom soils (WKS-A; WKS-B; WKS-C). The GPS coordinates are (BLS-A: $29^{\circ} 11^{\prime} 49.53^{\prime \prime S}$; $26^{\circ} 12^{\prime} 52.55^{\prime \prime}$ ); (BLS-B: $29^{\circ} 08^{\prime} 04.40^{\prime \prime} \mathrm{S}$; $26^{\circ} 15^{\prime} 58.10^{\prime \prime E}$ ); (BLS-C: $29^{\circ} 06^{\prime} 48.20^{\prime \prime S}$; $26^{\circ} 10^{\prime} 56.70^{\prime \prime} \mathrm{E}$ ); (WBS-A: $28^{\circ} 30^{\prime} 43.5^{\prime \prime} \mathrm{S} ; 27^{\circ} 00^{\prime} 12.8^{\prime \prime} \mathrm{E}$ ); (WBS-B: $28^{\circ} 30^{\prime}$ $59.8^{\prime \prime S}$; $27^{\circ} 00^{\prime} 58.0^{\prime \prime} \mathrm{E}$ ); (WBS-C: $28^{\circ} 31^{\prime} 08.00^{\prime \prime} \mathrm{S}$; $27^{\circ} 00^{\prime} 22.00^{\prime \prime E}$ ); (WKS-A: $\left.27^{\circ} 57^{\prime} 51.8^{\prime \prime} \mathrm{S} ; 26^{\circ} 45^{\prime} 36.9^{\prime \prime} \mathrm{E}\right)$; (WKS-B: $28^{\circ} 00^{\prime} 12.10^{\prime \prime} \mathrm{S} ; 26^{\circ} 43^{\prime}$ 52.30"E); (WKS-C: $\left.27^{\circ} 58^{\prime} 15.10^{\prime \prime S} ; 26^{\circ} 43^{\prime} 05.00^{\prime \prime} \mathrm{E}\right)$. The following laid down protocols and standards are utilized to assess the physical and hydro-mechanical properties of these soils: Sieve analysis [13]; Hydrometer analysis [14]; Atterberg limits [15]; Free swell ratio [8]; Specific gravity [16]; Linear shrinkage [17]; Proctor compaction test [18]; Zero swelling test [19]; Soil suction measurement using filter paper technique [20].

\subsection{Swelling Stress Test}

The swelling stress is the maximum external load that is required to prevent swelling soil from any further deformation while wet. Engineers usually measure the swelling stress in the laboratory using a conventional consolidometer setup. Reference $[21,22]$ reported that the zero swell tests (ZST) are an efficient method to determine the swelling stress of heaving soil. The swelling stress test is performed on compacted specimens according to reference [19]. Before submerging the soil specimen in water, the load bar was reset to zero to measure the vertical displacement of the compacted soil specimens. Making use of tap water is used to soak the soil specimen, and the surcharge was added in small increments to prevent the swell of the soil specimen. The process continues until the soil specimen ceases to expand. The test stops when there is no further deformation for several hours. The deformation must be less than 0.05 . The swelling stress is the total stress applied to prevent the specimen from swelling. Figure 1 shows the setup used to assess the swelling stress. The total surcharge in $\mathrm{kg}$ is $\left(\sum \mathrm{M}_{\mathrm{i}}\right)$, the gravity in $\mathrm{m} . \mathrm{s}^{-2}$, is $(\mathrm{g})$, the beam ratio in $\mathrm{m}$ is $\left(\mathrm{b}_{\mathrm{r}}\right)$, the number of the surcharge is $(n)$, the internal diameter of the consolidating ring in $m$ is $(\varphi)$. The swelling stress is $\left(\mathrm{P}_{\mathrm{s}}\right)$ in $\mathrm{kPa}$, and given in Equation (9).

$$
P_{S}=\frac{\frac{\left[\sum_{i=1}^{n} M_{i}\right] \times g \times b_{r}}{\frac{\pi \times \varphi^{2}}{4}}}{1000}
$$

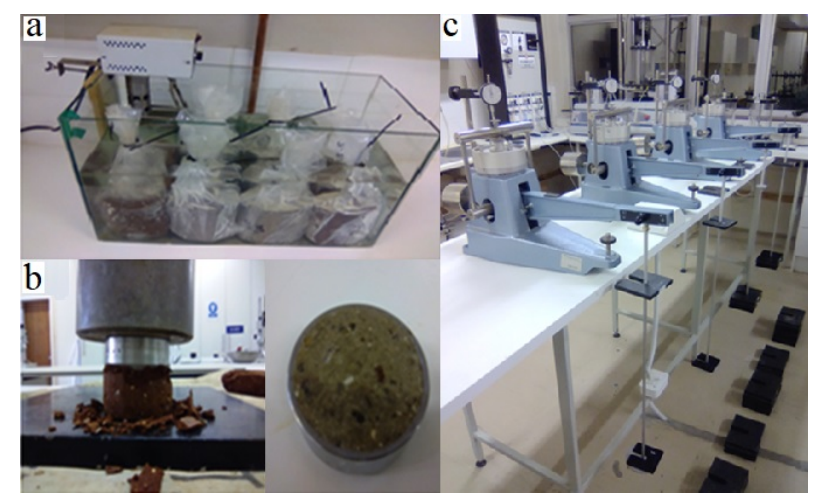

Figure 1. (a) Compacted specimens wrapped in an airtight plastic bag and kept in a constant temperature bath. b) Compacted specimens inserted in a ring using a jack. (c) A view of a conventional consolidometer setup.

\subsection{Soil Suction Measurement}

Compacted soil specimens are divided into two cylindrical parts with a width of $75 \mathrm{~mm}$ and a depth of 35 $\mathrm{mm}$ so that the soil specimen can be placed and removed from the glass jar easily. The soil suction estimation test performed using the Whatman No 42 type filter paper (Ashless circles $70 \mathrm{~mm}$ diameter, Cat No 1442-070). Three filter papers (two protectives and one for suction assessment with $70 \mathrm{~mm}$ diameter) are placed between these two surfaces using tweezers for matric suction assessment. The two cylindrical specimens' parts are joined using electrical tape and placed into a glass jar. The plastic ring is placed on top of the soil specimen. Also, the 
filter papers are placed on top of the plastic ring to measure the total suction. The glass jars are labeled, sealed, and put into a temperature regulatory apparatus at $25 \pm 1^{\circ} \mathrm{C}$ for an equilibrium period of four weeks. Moisture tins are oven-dried at $105^{\circ} \mathrm{C}$ overnight. The calibration curve Equation (10) is established by a calibration process of the filter paper using a salt solution. The moisture content within the filter paper, designated by $\left(\mathrm{W}_{\mathrm{f}}\right)$, is estimated using Equation (11). After, the calculated moisture content is substituted in Equation (10) to determine the soil suction. Water content within the filter paper is measured using a $0.0001 \mathrm{~g}$ readable balance. The mass of water in the filter paper is $\left(\mathrm{M}_{\mathrm{w}}\right)$, and the filter paper mass is $\left(\mathrm{M}_{\mathrm{f}}\right)$. Equation (10) describes the soil suction $(\Psi)$ in $\mathrm{kPa}$.

$$
\begin{gathered}
\log (\Psi)=-0.0791 \times \mathrm{W}_{\mathrm{f}}+5 \\
\mathrm{~W}_{\mathrm{f}}=\frac{\mathrm{M}_{\mathrm{w}}}{\mathrm{M}_{\mathrm{f}}} \times 100
\end{gathered}
$$

\subsection{Multivariate Regression Analysis}

The regression method describes a multifactor data analysis. The regression analysis formulates equations or models that link the dependent variables and independent variables. In this research work, NCSS.11 Program is utilized to perform regression analysis. The swelling stress is the dependent variable, and the independent variables are classified as follows: Matric suction, geotechnical index properties, and swelling soil indexes. Reference [23] stated that the predictive multi-linear model takes the form of Equation (12), the intercept is $\left(\beta_{0}\right)$, the regression coefficient is $\left(\beta_{\mathrm{i}}\right)$, the number of relevant soil parameters is $(\mathrm{n})$, the independent variable is $\left(\mathrm{X}_{\mathrm{i}}\right)$, and the random error is $(\varepsilon)$.

$$
\mathrm{Y}=+\beta_{\mathrm{o}}+\sum_{\mathrm{i}=1}^{\mathrm{n}}\left(\beta_{\mathrm{i}} \mathrm{X}_{\mathrm{i}}+\varepsilon\right)
$$

For curve estimation procedure, regression statistics are performed for different regression models, including linear, logarithmic, inverse, quadratic, cubic, power, compound, growth, and exponential models. The results revealed that linear function exhibits the strongest and suitable choice. Moreover, the transformation of a non-normal dependent variable into a normal dependent variable is achieved by the Box-Cox transformation function to enhance the accuracy of the model.

\section{Results and Discussion}

\subsection{Material Properties}

Table 2 presents a summary of soil properties. WKS-C displays a higher amount of clay fraction estimated at $55.25 \%$, whereas BLS-A displays a smaller amount of clay fraction estimated at $30.4 \%$. WKS-C soil displays a higher PI estimated at $56.68 \%$, whereas BLS-A displays a lower PI of 36.82. The amount of fine-grained in the soil sample determines these results. WKS-C contained a higher fine-grained amount of $82.98 \%$ while BLS-A a smaller amount estimated at $59.51 \%$. The results of Casagrande's plasticity chart revealed that BLS, WBS, and WKS are soils of high plasticity $(\mathrm{CH})$. Soil compaction enhances some desirable properties such as the increment of the shear stress, bearing limit, reduction of permeability, etc. WKS displays a smaller MDD and a higher OWC, whereas BLS exhibits the smaller OWC and the MDD. The fine-grained content influences the results. The dry density reduces, and the OWC increases simultaneously when the fine-grained fraction increases. In Table 2, (LL) is the liquid limit, (PI) the plasticity index, (LS) the linear shrinkage, (MDD) the maximum dry density, (OWC) the optimum water content, (Gs) the specific gravity, and the Unified Soil Classification

\begin{tabular}{|c|c|c|c|c|c|c|c|c|c|c|}
\hline \multicolumn{2}{|c|}{ Soil Designation } & \multirow{2}{*}{$\begin{array}{c}\begin{array}{c}\text { LL } \\
(\%)\end{array} \\
58.98 \\
\end{array}$} & \multirow{2}{*}{$\begin{array}{c}\begin{array}{c}\text { PI } \\
(\%)\end{array} \\
36.82 \\
\end{array}$} & \multirow{2}{*}{$\begin{array}{c}\begin{array}{c}\text { LS } \\
(\%)\end{array} \\
9.28\end{array}$} & \multirow{2}{*}{$\begin{array}{c}\begin{array}{c}\text { Fine- } \\
\text { grained } \\
(\%)\end{array} \\
59.51 \\
\end{array}$} & \multirow{2}{*}{$\begin{array}{c}\text { Gravel } \\
(\%)\end{array}$} & \multirow{2}{*}{$\begin{array}{c}\mathrm{MDD} \\
\mathrm{kN} / \mathrm{m}^{3}\end{array}$} & \multirow{2}{*}{$\begin{array}{c}\begin{array}{c}\text { OWC } \\
\%\end{array} \\
20.07 \\
\end{array}$} & \multirow{2}{*}{$\begin{array}{c}\text { Gs } \\
2.64 \\
\end{array}$} & \multirow{2}{*}{$\begin{array}{c}\text { USCS } \\
\mathrm{CH}\end{array}$} \\
\hline \multirow{3}{*}{ BLS } & BLS-A & & & & & & & & & \\
\hline & BLS-B & 61.27 & 38.25 & 8.93 & 61.82 & 8.38 & 17.16 & 22.61 & 2.68 & $\mathrm{CH}$ \\
\hline & BLS-C & 64.6 & 40.33 & 8.471 & 65.18 & 4.32 & 16.95 & 23 & 2.71 & $\mathrm{CH}$ \\
\hline \multirow{3}{*}{ WBS } & WBS-A & 63.78 & 42.48 & 7.69 & 67.52 & 4.85 & 16.85 & 24.03 & 2.73 & $\mathrm{CH}$ \\
\hline & WBS-B & 66.22 & 44.10 & 7.41 & 70.1 & 2.45 & 16.71 & 24.58 & 2.76 & $\mathrm{CH}$ \\
\hline & WBS-C & 70.64 & 47.04 & 6.97 & 74.78 & 1.21 & 16.45 & 26.05 & 2.78 & $\mathrm{CH}$ \\
\hline \multirow{3}{*}{ WKS } & WKS-A & 69.45 & 49.87 & 6.12 & 73 & 2.56 & 16.29 & 26.14 & 2.73 & $\mathrm{CH}$ \\
\hline & WKS-B & 74.31 & 53.36 & 5.72 & 78.11 & 1.98 & 16.05 & 26.52 & 2.78 & $\mathrm{CH}$ \\
\hline & WKS-C & 78.94 & 56.68 & 5.38 & 82.98 & 1.1 & 15.65 & 27.75 & 2.83 & $\mathrm{CH}$ \\
\hline
\end{tabular}
System (USCS).

Table 2. Material properties 


\subsection{Swelling Properties and Soil Mineralogy}

Reference [24] investigated the swelling properties of Baghmished marls. The result of the study revealed that the type of clay mineral has a significant impact on the swelling properties of marls. The swelling properties are determined using the free swell ratio (FSR) test proposed by [8]. Table 3 presents a summary of the results. WKS soils show a high capacity of expansiveness with FSR values within the range of 2 to 4 . However, WBS soils and BLS soils display a moderate potential of expansiveness with FSR values ranging from 1.5 to 2 . Besides, the smectite (montmorillonite) is the predominant clay mineral across the region of study. The soil mineralogy characteristic is in line with the results of the research work conducted by [28]. Reference [28] investigated the soil mineralogy of heaving soils using some soil parameters.

Table 3. Free swell ratio test results

\begin{tabular}{|c|c|c|c|c|}
\hline $\begin{array}{c}\text { Soil } \\
\text { designation }\end{array}$ & $\begin{array}{c}\text { Free } \\
\text { swell } \\
\text { ratio } \\
\text { (FSR) }\end{array}$ & $\begin{array}{c}\text { Clay } \\
\text { type }\end{array}$ & $\begin{array}{c}\text { Soil } \\
\text { expansivity }\end{array}$ & $\begin{array}{c}\text { Dominant } \\
\text { clay mineral } \\
\text { type. }\end{array}$ \\
\hline BLS-A & 1.64 & Swelling & Moderate & Montmorillonitic \\
\hline BLS-B & 1.7 & Swelling & Moderate & Montmorillonitic \\
\hline BLS-C & 1.79 & Swelling & Moderate & Montmorillonitic \\
\hline WBS-A & 1.73 & Swelling & Moderate & Montmorillonitic \\
\hline WBS-B & 1.8 & Swelling & Moderate & Montmorillonitic \\
\hline WBS-C & 1.92 & Swelling & Moderate & Montmorillonitic \\
\hline WKS-A & 2.2 & Swelling & High & Montmorillonitic \\
\hline WKS-B & 2.35 & Swelling & High & Montmorillonitic \\
\hline WKS-C & 2.5 & Swelling & High & Montmorillonitic \\
\hline
\end{tabular}

\subsection{Analysis of the Relationship between Soil Suctions and Water Content}

Assessment of the correlation between the soil suction (total, matric, and osmotic suction) and water content for each soil sample. Figures. 2, $3 \& 4$ show the variation of the total suction, matric suction, and osmotic suction with respect to water content respective for BLS-A, BLS-B, BLS-C. Figure 5 describes the correlation between matric suction and water content for BLS-A, BLS-B, BLS-C. Further, BLS-C displays respectively higher total suction and matric suction values estimated at $6444.53 \mathrm{kPa}$ and $5193.39 \mathrm{kPa}$. BLS-A displays the smaller total and matric suction values respectively $340.04 \mathrm{kPa}$ and $200.00 \mathrm{kPa}$. The difference in fine-grained fraction determines these results. BLS-C exhibits a higher quantity of fine-grained fraction estimated at $65.18 \%$, and BLS-A a smaller amount of fine-grained fraction of the order of $59.51 \%$.



Figure 2. Soil suction vs Water content (BLS-A)

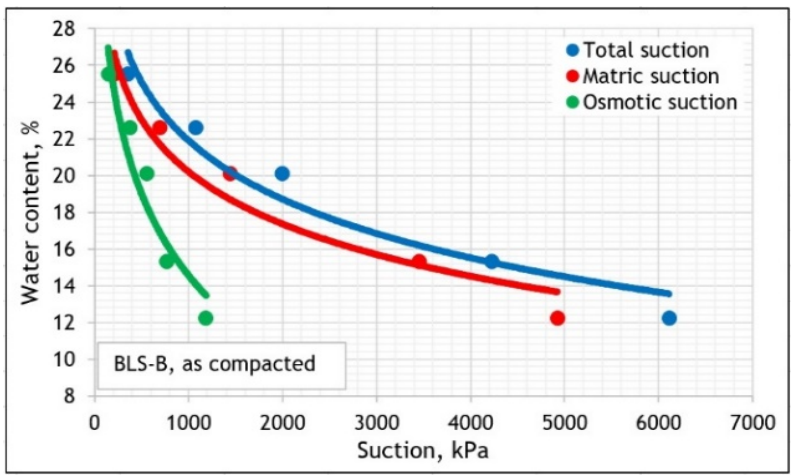

Figure 3. Soil suction vs Water content (BLS-B)

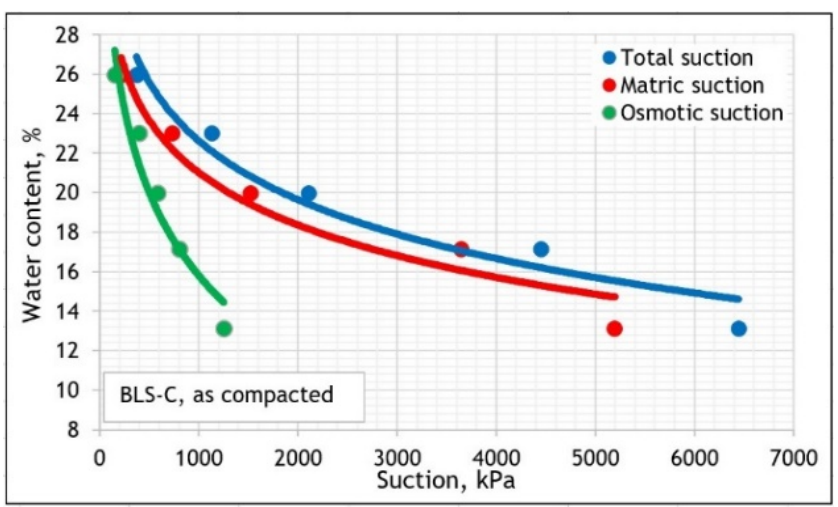

Figure 4. Soil suction vs Water content (BLS-C)

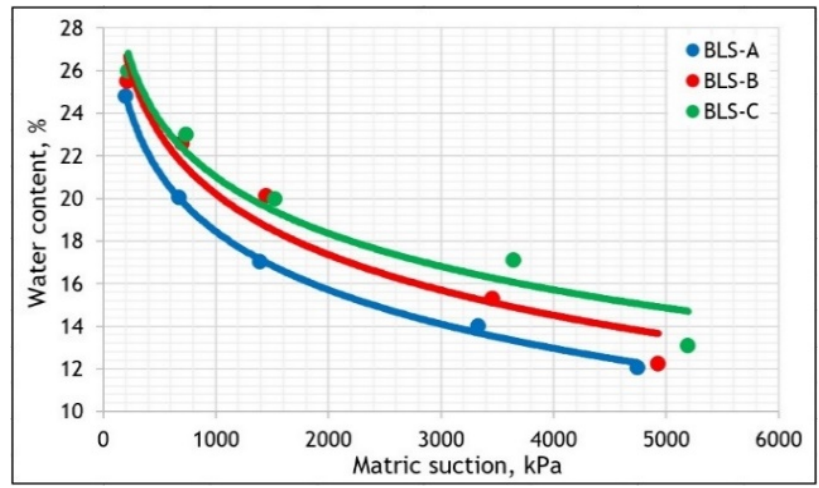

Figure 5. Matric suction vs Water content (BLS) 
Figures. $6,7 \& 8$ show the variation of total suction, matric suction, and osmotic suction with water content respectively for WBS-A, WBS-B, WBS-C. Figure 9 exhibits the variation of matric suction with water content for WBS-A, WBS-B, WBS-C. As a result, WBS-C displays the higher total suction and matric suction estimated respectively at $8239.04 \mathrm{kPa}$, and $6628.04 \mathrm{kPa}$. WBS-A exhibits the smaller total suction and matric suction estimated respectively at $816.77 \mathrm{kPa}$, and 450.23 $\mathrm{kPa}$. The fine-grained content impacts these results. WBS-C displays a higher quantity of fine-grained fraction estimated at $74.78 \%$, and WBS-A exhibits a smaller amount of fine-grained fraction evaluated at $67.52 \%$.

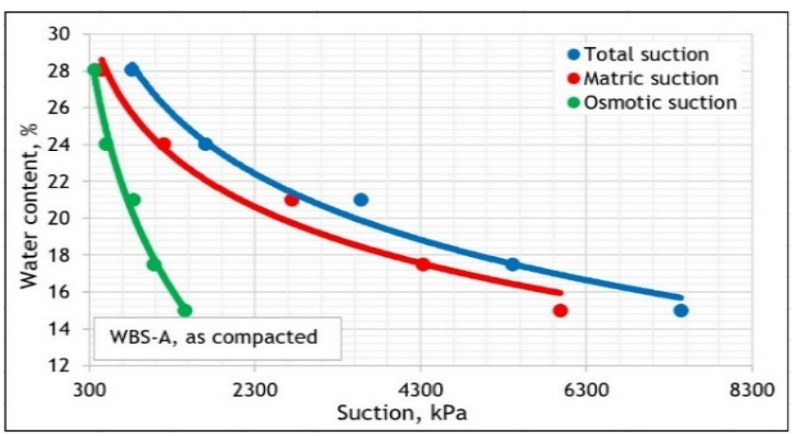

Figure 6. Soil suction vs Water content (WBS-A)

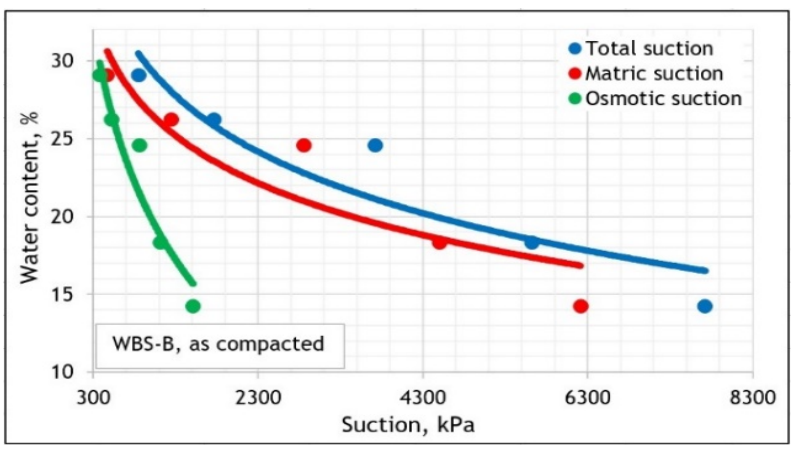

Figure 7. Soil suction vs Water content (WBS-B)

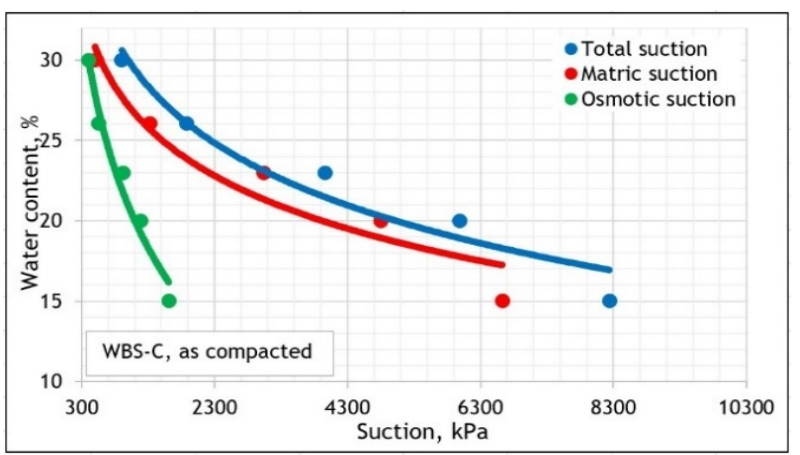

Figure 8. Soil suction vs Water content (WBS-C)

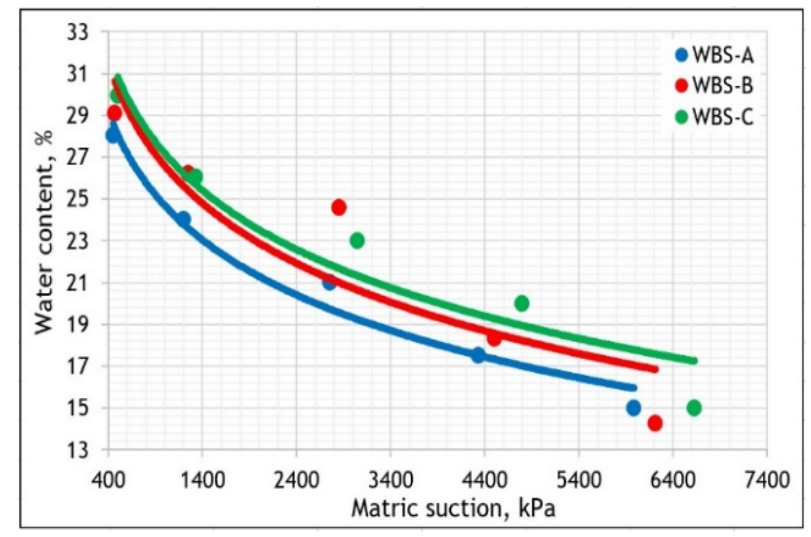

Figure 9. Matric suction vs Water content (WBS)

Investigation of the relationship between soil suctions (total suction, matric suction, osmotic suction) and water content for each soil specimen. Figures. 10, 11 \& 12 show the variation of total suction, matric suction, and osmotic suction with water content respective for WKS-A, WKS-B, WKS-C. Figure 13 exhibits the variation of matric suction with water content for WKS-A, WKS-B, WKS-C. Also, WKS-C displays the higher total suction and matric suction values estimated respectively at $11283.21 \mathrm{kPa}$, and $8745.48 \mathrm{kPa}$. On the contrary, WKS-A shows the smaller total suction and matric suction estimated respectively at $1397.75 \mathrm{kPa}$ and $890.47 \mathrm{kPa}$. The reason is the fact that WKS-C contained a higher quantity of fine-grained fraction estimated at $82.98 \%$, while WKS-A displays the smaller amount of fine-grained fraction evaluated at $73 \%$. WKS soils exhibit higher values of suction and BLS the smaller values of suction. The reason is the fact that WKS soil contained the higher fine-grained fraction while BLS the smaller fine-grained fraction. Therefore, the suction values within a compacted heaving soils increase when the fine-grained fraction within the soil increases. The total suction values are within the range of $340.04 \mathrm{kPa}$ to $11283.21 \mathrm{kPa}$, and the matric suction values ranging from $200 \mathrm{kPa}$ to $8745.41 \mathrm{kPa}$. However, at OWC, the total suction values are within the range of $1036.11 \mathrm{kPa}$ to $1881.75 \mathrm{kPa}$, and the matric suction values ranging from $671.89 \mathrm{kPa}$ to $1328.33 \mathrm{kPa}$. The total suction and matric suction curves are very similar in shape, especially within the range of higher water content. Nonetheless, the osmotic suction curve shape is very different from others. Therefore, the matric suction contribution to the total suction is higher than the osmotic suction. 


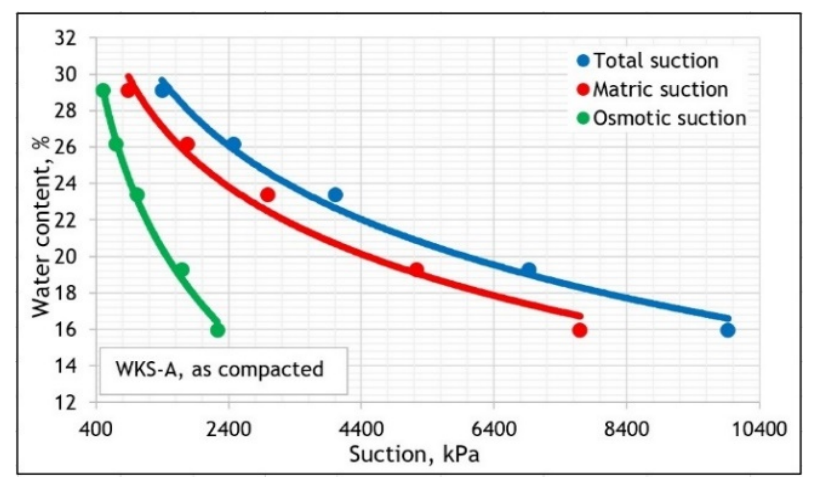

Figure 10. Soil suction vs Water content (WKS-A)

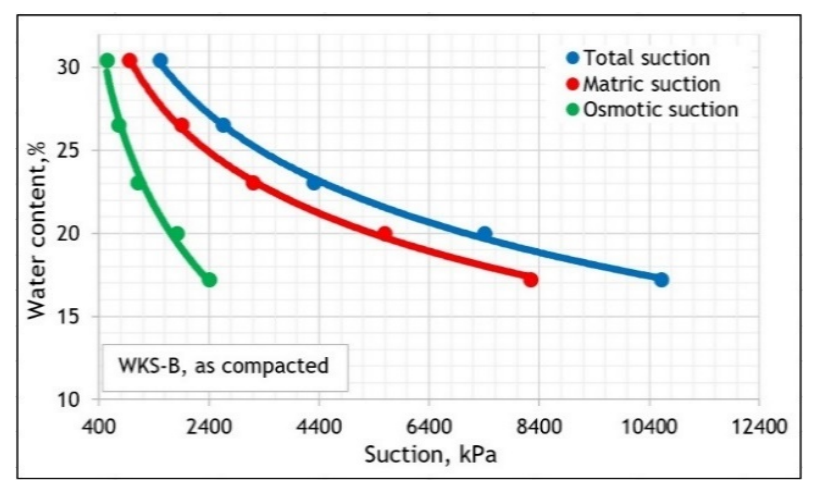

Figure 11. Soil suction vs Water content (WKS-B)

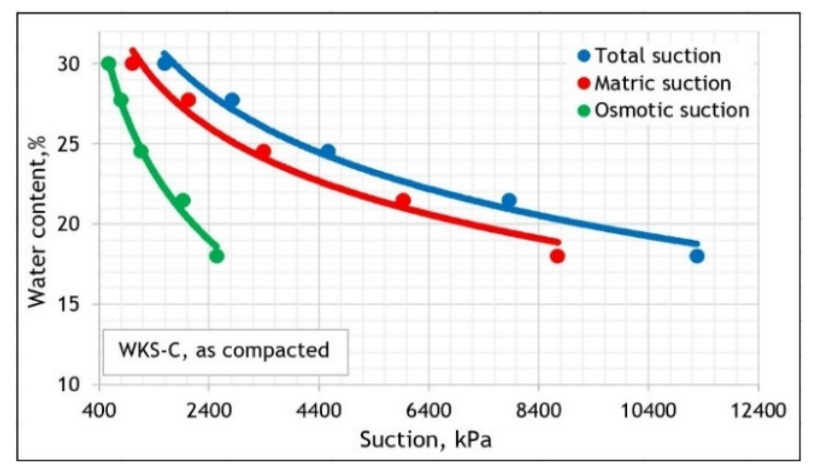

Figure 12. Soil suction vs Water content (WKS-C)

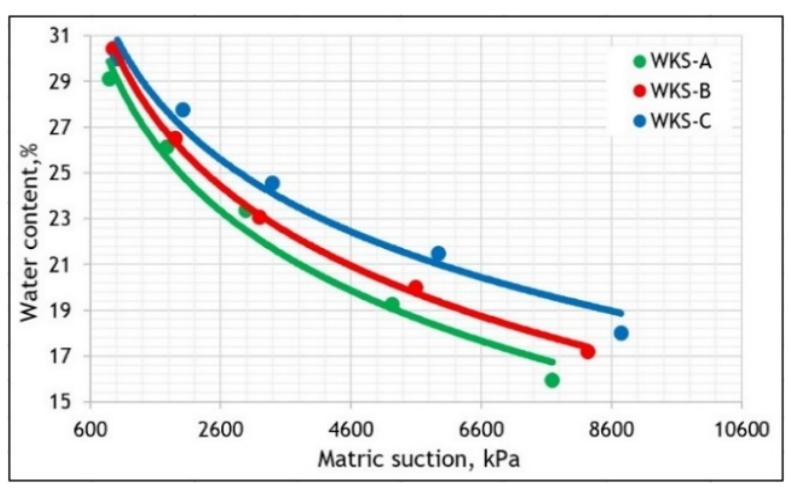

Figure 13. Matric suction vs Water content (WKS)

\subsection{Analysis of the Relationship between Swelling Stress and Soils Properties}

A correlation is established by plotting the experimental values between the swelling stress and matric suction presented in Figure 14. There is a tendency of increment of swelling stress when the matric suction increases and describes an exponential relationship for soil specimens BLS, WBS, and WKS with a determination coefficient of $85.5 \%$. The scatters of the plotted data are in good coordination and show marginal discrepancies. The results are in line with the studies conducted by [25] on the correlation between swelling stress and soil suction which revealed that the swelling stress increases when the soil suction increases. Therefore, soil suction is a significant parameter to be used for the prediction of swelling stress of heaving soils. Also, the investigation conducted by [26] on the swelling stress and swell index from the suction test on pre-compacted Neogene clays in Poland (Warsaw) shows an exponential correlation swelling stress and the suction. The suction increases when swelling stress increase. To investigate the correlation between the swelling stress and the initial dry unit weight at OWC. Figure 15 shows the plot of experimental swelling stress values versus the initial dry unit weight. The swelling stress decreases with the increment of the initial dry unit weight and the correlation exhibits an exponential relationship for the soil samples BLS, WBS, and WKS with a determination coefficient of $82.6 \%$. The plotted data display marginal discrepancies. These results did not concord with the outcome of the investigation conducted by [27] on the behaviour of clay collected from various locations across India, which stated that the swelling stress instead increases as the initial dry density increases. The discrepancies in this research work originated from the fact that the correlation is at OWC between the swelling stress and initial dry unit weight. The swelling stress and the initial water content values are plotted in Figure 16 to analyze the correlation between the two parameters at OWC. The swelling stress shows a tendency to increase as the initial water content increases. The reason is that at the OWC, the maximum air void within the soil particles reduces, and the unit weight does not longer increase upon water addition. There is a good correlation between the swelling stress and the initial water content with a determination coefficient of $80.2 \%$. The results concord with the outcome of the investigation conducted by [27] on the behaviour of clay collected from various locations across India, which revealed that the swelling stress increases as the initial water content increases. To assess the interrelation between the swelling stress and the PI, experimental data values of the swelling stress versus PI is shown in Figure 17. The swelling stress increases when the PI increases and exhibits an exponential relationship for soil samples BLS, WBS, and WKS with a determination coefficient of $83.7 \%$. There is a good correlation between the swelling stress and the PI. Therefore, the PI has a significant impact on swelling stress values. Reference [7] pointed out that the increment of the PI significantly increases the swelling stress of 
heaving soils.

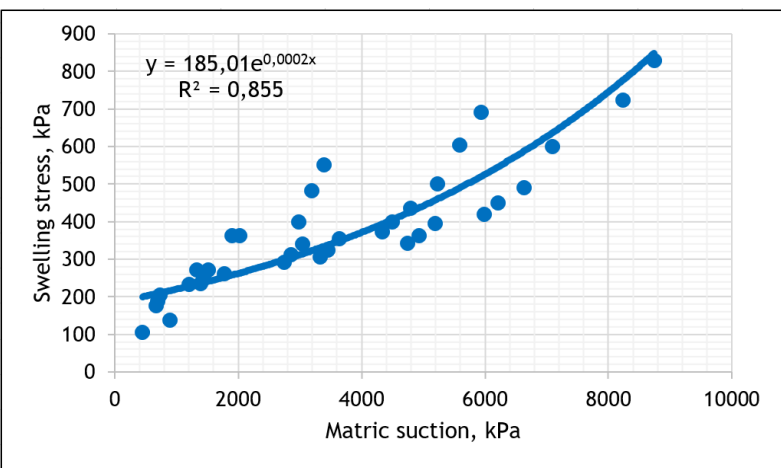

Figure 14. Swelling stress vs matric suction

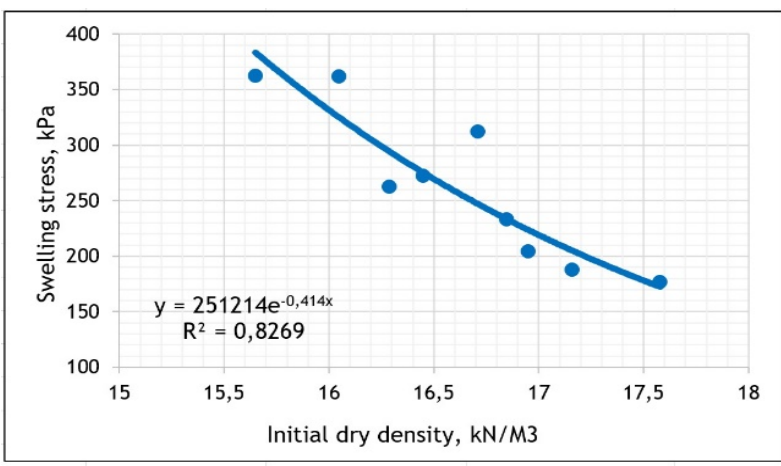

Figure 15. Swelling stress vs dry density @ OWC

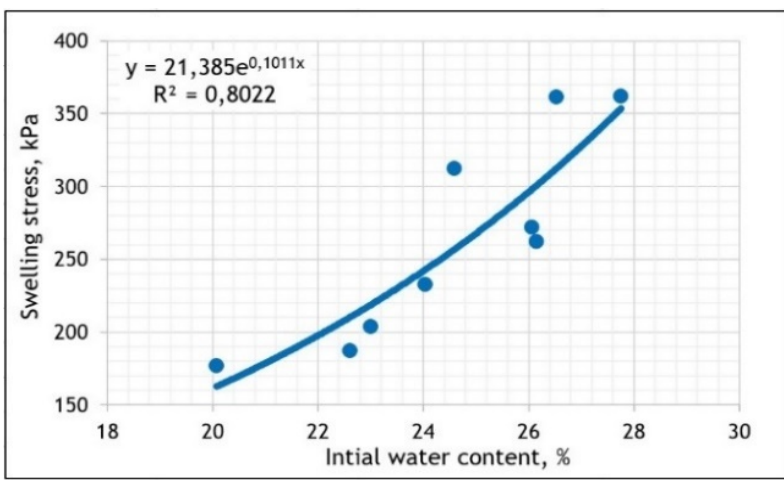

Figure 16. Swelling stress vs initial water content @ OWC

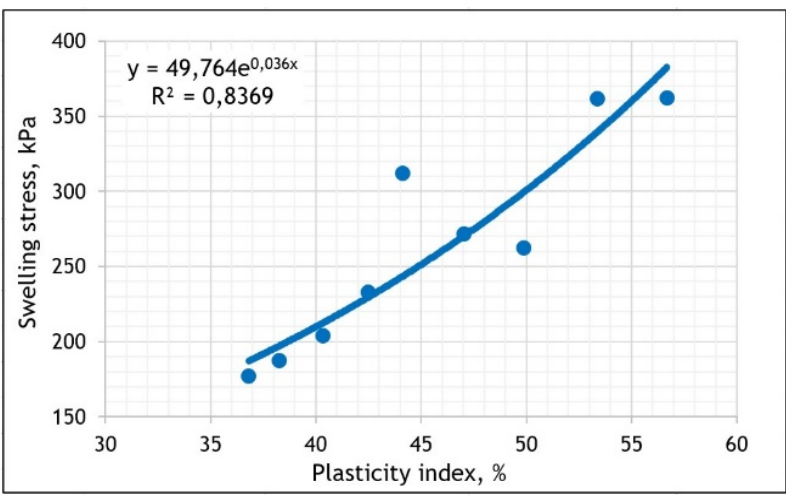

Figure 17. Swelling stress vs plasticity index @ OWC
Figure 18 presents the plotted data used to analyze the correlation between the swelling stress and the linear shrinkage of field compacted heaving soils. There is a tendency to decrease swelling stress when the linear shrinkage increases. The resulting trend is an exponential relationship with a determination coefficient of $84.8 \%$. The data set exhibits a high strength correlation. Besides, at OWC, an increment of the linear shrinkage from 5.38 $\mathrm{kPa}$ to $9.28 \mathrm{kPa}$ induces a significant reduction of the values of the swelling stress from $362.30 \mathrm{kPa}$ to 176.88 $\mathrm{kPa}$. Therefore, the linear shrinkage influences swelling stress. Figure 19 presents a correlation between the swelling stress and the free swell ratio. The swelling stress increases when the free swell ratio increases and displays an exponential relation with a strong determination coefficient of $80.4 \%$. The scatter plotted data exhibit a good correlation with small discrepancies. At OWC, an increment of the free swell ratio variation from 1.64 to 2.50 induces a significant increment of the swelling stress values from $362.30 \mathrm{kPa}$ to $176.88 \mathrm{kPa}$. Reference [8] pointed out that the FSR is a very competitive method to assess the swelling behaviour of heaving soils and clay mineralogy.

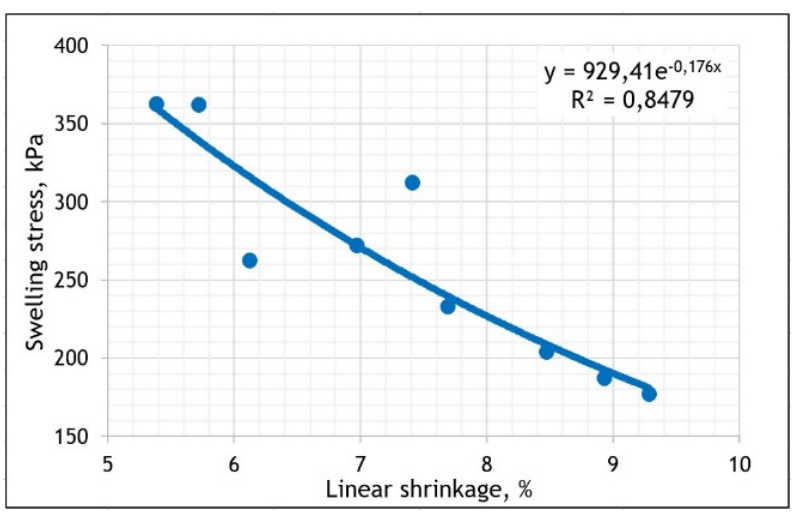

Figure 18. Swelling stress vs Linear shrinkage @ OWC

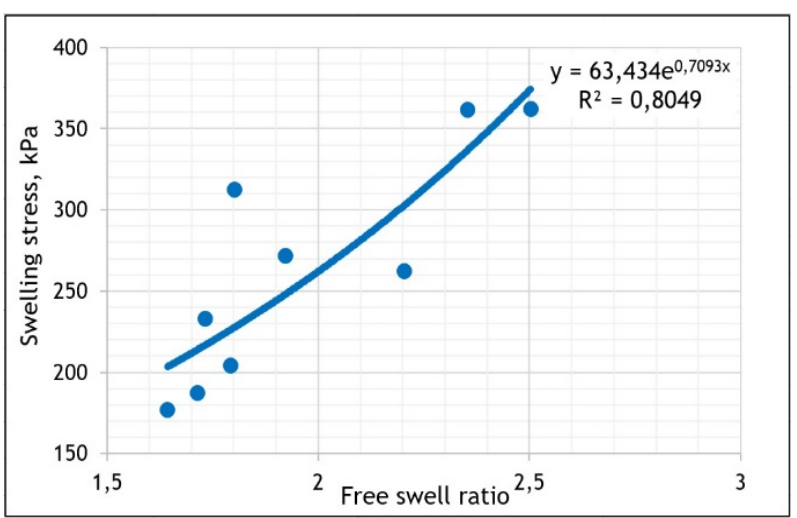

Figure 19. Swelling stress vs FSR @ OWC

The swelling stress interaction with the matric suction, initial water content, initial dry unit weight, PI, linear shrinkage, and the free swell ratio is analyzed using a 3D surface plot and represented in Figures. 20, $21 \& 22$. The 
three-dimensional surface plot in Figure 20 describes the interaction between the swelling stress, matric suction, and initial water content. The minimum values of the swelling stress are within the range of $105 \mathrm{kPa}$ to $185 \mathrm{kPa}$, and the maximum values of the swelling stress are within $748 \mathrm{kPa}$ to $828 \mathrm{kPa}$. The swelling stress increases when the matric suction increases. Also, there is a tendency of the swelling stress values to decrease when the initial water content increases. Besides, the three-dimensional surface plot in Figure 21 describes the correlation between the swelling stress, initial dry unit weight, and PI. The minimum values of the swelling stress are within the range of $106 \mathrm{kPa}$ to $186 \mathrm{kPa}$, and the maximum values of the swelling stress are within $747 \mathrm{kPa}$ to $828 \mathrm{kPa}$. The swelling stress decreases when the initial dry unit weight increases. Besides, the swelling stress values increase when the PI increases. The surface plot in Figure 22 portrays the correlation between the swelling stress, linear shrinkage, and free swell ratio. The minimum values of the swelling stress are within the range of $224 \mathrm{kPa}$ to 270 $\mathrm{kPa}$, and the maximum values of the swelling stress are within $587 \mathrm{kPa}$ to $633 \mathrm{kPa}$. The swelling stress decreases when the linear shrinkage increases. Further, the swelling stress values increase when the free swell ratio increases.



Figure 20. Surface plot: swelling stress vs matric suction. water content

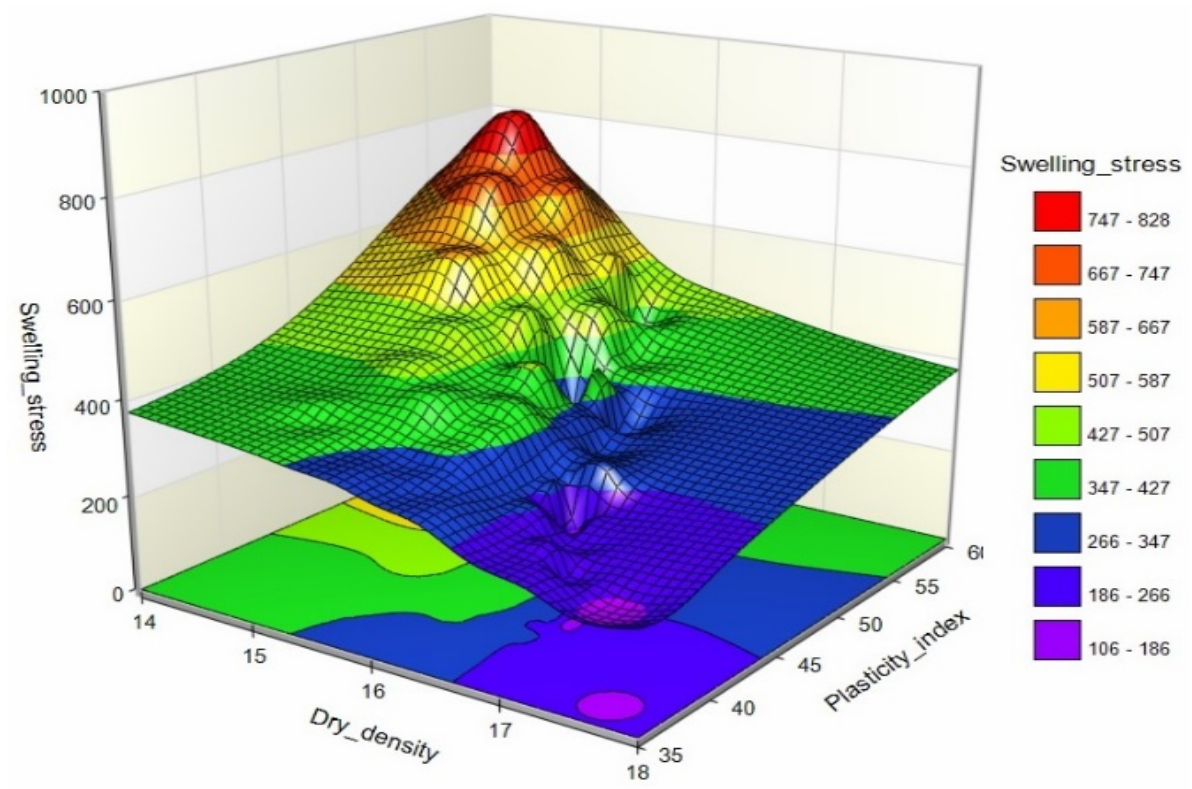

Figure 21. Surface plot: swelling stress vs dry density. plasticity index 




Figure 22. Surface plot: swelling stress vs linear shrinkage. free swell ratio

\section{Models Development}

\subsection{Estimated Models}

Paragraph 2.3 describes the multivariate regression analysis performed in this research work. The swelling stress is the dependent variable, and the independent variables are as follows: matric suction, initial dry unit weight, initial water content, plasticity index, linear shrinkage, and free swell ratio. Moreover, Paragraph 3.4 gives the criteria for the selection of the soil parameters as independent variables. Tables 5,6 \&7 show the respective correlation matrices $\mathrm{A}, \mathrm{B}, \& \mathrm{C}$ related to regression analysis with the NCSS.11 Program. The predictive mathematical Equation (13) below consists of the following independent variables: matric suction $\left(\Psi_{\mathrm{m}}\right)$, initial water content $\left(\mathrm{W}_{\mathrm{i}}\right)$, initial dry unit weight $\left(\gamma_{\mathrm{d}}\right)$, plasticity index $(\mathrm{PI})$, linear shrinkage $\left(\mathrm{L}_{\mathrm{s}}\right)$, free swell ratio
(FSR), the intercept $\xi_{0}$, and coefficients of correlation $\xi_{1}, \xi_{2}$, $\xi_{3}, \xi_{4}, \xi_{5}, \xi_{6}$. Table 4 summarized the values of the regression analysis coefficients.

$$
\begin{aligned}
& {\left[\log \mathrm{P}_{\mathrm{s}}\right]^{j}=-\xi_{0}+\xi_{1} \times \log \left(\Psi_{\mathrm{m}}\right)-\xi_{2} \times \mathrm{W}_{\mathrm{i}}+} \\
+ & \xi_{3} \times \gamma_{\mathrm{d}}+\xi_{4} \times \log (\mathrm{PI})+\xi_{5} \times \mathrm{L}_{\mathrm{s}}+\xi_{6} \times 10^{\mathrm{FSR}}
\end{aligned}
$$

Where:

$\mathrm{P}_{\mathrm{s}}=$ swelling stress, $\mathrm{kPa}$,

$\Psi_{\mathrm{m}}=$ matric suction, $\mathrm{kPa}$,

$\mathrm{W}_{\mathrm{i}}=$ initial water comtent, $\%$,

$\gamma_{\mathrm{d}}=$ initial dry unit weight, $\mathrm{kN} / \mathrm{m} 3$,

$\mathrm{PI}=$ plasticity index, $\%$,

$\mathrm{L}_{\mathrm{s}}=$ linear shrinkage, $\%$,

$\mathrm{FSR}=$ free swell ratio,

$\lambda=2$, Box-Cox transformation coefficient,

$\xi_{0}=$ intercept,

$\xi_{i}=$ multi-regression coefficient, $i=1, \ldots \ldots 6$ 
Table 4. Regression coefficients and summary report

\begin{tabular}{|c|c|c|c|c|c|c|}
\hline \multirow{2}{*}{ Regression coefficients } & $\xi_{1}$ & $\xi_{2}$ & $\xi_{3}$ & $\xi_{4}$ & $\xi_{5}$ & $\xi_{6}$ \\
\hline & 1.658 & 0.1279 & 0.5949 & 28.39 & 0.720 & 0.001405 \\
\hline Intercept & \multicolumn{6}{|c|}{$\xi_{0}=-58.50$} \\
\hline \multirow[t]{2}{*}{ Summary report } & \multicolumn{2}{|c|}{$\begin{array}{c}\text { Correlation } \\
\text { coefficient, } \mathrm{R}^{2}\end{array}$} & \multicolumn{2}{|c|}{$\begin{array}{c}\text { Relative standard deviator, } \\
\text { RSD } \\
\end{array}$} & \multicolumn{2}{|c|}{$\begin{array}{c}\text { Mean square error, } \\
\text { MSE }\end{array}$} \\
\hline & \multicolumn{2}{|c|}{$97.9 \%$} & \multicolumn{2}{|c|}{$2.48 \%$} & \multicolumn{2}{|c|}{0.0040} \\
\hline
\end{tabular}

Table 5. Correlation Matrix A

\begin{tabular}{|c|c|c|c|c|c|c|}
\hline \multicolumn{2}{|c|}{ Soil designation } & LL(\%) & PL (\%) & PI (\%) & LS (\%) & FSR \\
\hline \multirow{3}{*}{ BLS } & BLS-A & 58.98 & 22.16 & 36.82 & 12.56 & 1.64 \\
\hline & BLS-B & 61.27 & 23.02 & 38.25 & 12.11 & 1.7 \\
\hline & BLS-C & 64.6 & 24.27 & 40.33 & 11.47 & 1.79 \\
\hline \multirow{3}{*}{ WBS } & WBS-A & 63.78 & 21.31 & 42.48 & 10.73 & 1.73 \\
\hline & WBS-B & 66.22 & 22.12 & 44.10 & 10.32 & 1.8 \\
\hline & WBS-C & 70.64 & 23.6 & 47.04 & 9.59 & 1.92 \\
\hline \multirow{3}{*}{ WKS } & WKS-A & 69.45 & 19.58 & 49.87 & 8.76 & 2.2 \\
\hline & WKS-B & 74.31 & 20.95 & 53.36 & 8.18 & 2.35 \\
\hline & WKS-C & 78.94 & 22.26 & 56.68 & 7.702 & 2.5 \\
\hline
\end{tabular}

Table 6. Correlation Matrix B

\begin{tabular}{|c|c|c|c|c|c|c|c|c|}
\hline \multirow{2}{*}{\multicolumn{2}{|c|}{ Soil designation }} & Samples & $\begin{array}{l}\text { Initial } \\
\text { Water } \\
\text { content }\end{array}$ & $\begin{array}{c}\text { Swelling } \\
\text { stress }\end{array}$ & $\begin{array}{c}\text { Total } \\
\text { suction }\end{array}$ & $\begin{array}{l}\text { Matric } \\
\text { suction }\end{array}$ & $\begin{array}{l}\text { Osmotic } \\
\text { suction }\end{array}$ & $\begin{array}{c}\text { Initial dry } \\
\text { density }\end{array}$ \\
\hline & & & $\%$ & $\mathrm{kPa}$ & $\mathrm{kPa}$ & $\mathrm{kPa}$ & $\mathrm{kPa}$ & $\mathrm{kN} / \mathrm{m}^{3}$ \\
\hline \multirow{15}{*}{ WKS } & \multirow{5}{*}{ WKS-A } & WKS-A1 & 15.93 & 599.543 & 9926.183 & 7093.666 & 2832.517 & 14.94 \\
\hline & & WKS-A2 & 19.25 & 499.619 & 6922.321 & 5227.777 & 1694.544 & 15.48 \\
\hline & & WKS-A3 & 23.37 & 399.695 & 4011.482 & 2986.456 & 1025.026 & 16.09 \\
\hline & & WKS-A4 & 26.14 & 262.3 & 2475.62 & 1778.651 & 696.969 & 16.29 \\
\hline & & WKS-A5 & 29.1 & 137.395 & 1397.745 & 890.47 & 507.275 & 15.85 \\
\hline & \multirow{5}{*}{ WKS-B } & WKS-B1 & 17.2 & 724.098 & 10621.01 & 8232.22 & 2388.79 & 14.77 \\
\hline & & WKS-B2 & 19.98 & 603.415 & 7406.88 & 5593.72 & 1813.16 & 15.2 \\
\hline & & WKS-B3 & 23.05 & 482.731 & 4292.28 & 3195.51 & 1096.77 & 15.7 \\
\hline & & WKS-B4 & 26.52 & 361.792 & 2648.91 & 1903.16 & 745.754 & 16.05 \\
\hline & & WKS-B5 & 30.43 & 165.938 & 1495.59 & 952.8 & 542.79 & 15.41 \\
\hline & \multirow{5}{*}{ WKS-C } & WKS-C1 & 18 & 828.118 & 11283.21 & 8745.48 & 2537.73 & 14.61 \\
\hline & & WKS-C2 & 21.47 & 690.098 & 7868.687 & 5942.48 & 1926.207 & 15 \\
\hline & & WKS-C3 & 24.56 & 552.078 & 4559.901 & 3394.741 & 1165.16 & 15.49 \\
\hline & & WKS-C4 & 27.75 & 362.301 & 2814.07 & 2021.814 & 792.256 & 15.65 \\
\hline & & WKS-C5 & 30 & 189.776 & 1588.83 & 1012.2 & 576.63 & 15.21 \\
\hline
\end{tabular}


Table 7. Correlation Matrix $\mathrm{C}$

\begin{tabular}{|c|c|c|c|c|c|c|c|c|}
\hline \multirow{2}{*}{\multicolumn{2}{|c|}{ Soil designation }} & \multirow[t]{2}{*}{ Samples } & \multirow{2}{*}{$\begin{array}{c}\begin{array}{c}\text { Initial Water } \\
\text { content }\end{array} \\
\%\end{array}$} & \multirow{2}{*}{$\begin{array}{c}\begin{array}{c}\text { Swelling } \\
\text { stress }\end{array} \\
\mathrm{kPa}\end{array}$} & \multirow{2}{*}{$\begin{array}{c}\begin{array}{c}\text { Total } \\
\text { suction }\end{array} \\
\mathrm{kPa}\end{array}$} & \multirow{2}{*}{$\begin{array}{c}\begin{array}{c}\text { Matric } \\
\text { suction }\end{array} \\
\mathrm{kPa}\end{array}$} & \multirow{2}{*}{$\begin{array}{c}\begin{array}{c}\text { Osmotic } \\
\text { suction }\end{array} \\
\mathrm{kPa}\end{array}$} & \multirow{2}{*}{$\begin{array}{c}\text { Initial dry } \\
\text { unit weight } \\
\mathrm{kN} / \mathrm{m}^{3}\end{array}$} \\
\hline & & & & & & & & \\
\hline \multirow{15}{*}{ BLS } & \multirow{5}{*}{ BLS-A } & BLS-A1 & 12.06 & 341.975 & 5883.92 & 4741.62 & 1142.3 & 15.6 \\
\hline & & BLS-A2 & 14.02 & 306.598 & 4064.22 & 3327.18 & 737.04 & 16.21 \\
\hline & & BLS-A3 & 17.03 & 235.845 & 1923.09 & 1388.22 & 534.87 & 17.01 \\
\hline & & BLS-A4 & 20.07 & 176.883 & 1036.11 & 671.89 & 364.22 & 17.58 \\
\hline & & BLS-A5 & 24.8 & 129.714 & 340.034 & 200 & 140.034 & 17.2 \\
\hline & \multirow{5}{*}{ BLS-B } & BLS-B1 & 12.25 & 362.224 & 6112.321 & 4925.68 & 1186.641 & 15.15 \\
\hline & & BLS-B2 & 15.32 & 324.752 & 4221.982 & 3456.34 & 765.642 & 15.95 \\
\hline & & BLS-B3 & 20.12 & 249.81 & 1997.745 & 1442.11 & 555,635 & 16.98 \\
\hline & & BLS-B4 & 22.61 & 187.357 & 1076.324 & 697.98 & 378.344 & 17.16 \\
\hline & & BLS-B5 & 25.5 & 137.395 & 353.234 & 207.79 & 145.444 & 16,92 \\
\hline & \multirow{5}{*}{ BLS-C } & BLS-C1 & 13.11 & 394.509 & 6444.53 & 5193.39 & 1251.14 & 14.97 \\
\hline & & BLS-C2 & 17.12 & 353.697 & 4451,45 & 3644,19 & 807.26 & 15.98 \\
\hline & & BLS-C3 & 19.98 & 272.075 & 2106.33 & 1520.49 & 585.84 & 16.59 \\
\hline & & BLS-C4 & 23 & 204.056 & 1134.82 & 735.9 & 398.92 & 16.95 \\
\hline & & BLS-C5 & 25.97 & 149.641 & 372.43 & 219.08 & 153.35 & 16.6 \\
\hline \multirow{15}{*}{ WBS } & \multirow{5}{*}{ WBS-A } & WBS-A1 & 14.98 & 419.228 & 7439,15 & 5984,56 & 1454.59 & 15.6 \\
\hline & & WBS-A2 & 17.5 & 372.647 & 5410.66 & 4332.678 & 1077.982 & 16.05 \\
\hline & & WBS-A3 & 21 & 291.13 & 3580.89 & 2748.3 & 832.59 & 16,58 \\
\hline & & WBS-A4 & 24.03 & 232,905 & 1699.05 & 1199.35 & 499.7 & 16.85 \\
\hline & & WBS-A5 & 28.06 & 104.806 & 816.77 & 450.227 & 366.543 & 16.7 \\
\hline & \multirow{5}{*}{ WBS-B } & WBS-B1 & 14.25 & 449.657 & 7723,408 & 6213.234 & 1510.174 & 15.25 \\
\hline & & WBS-B2 & 18.32 & 399.695 & 5617.411 & 4498,234 & 1119.177 & 15.98 \\
\hline & & WBS-B3 & 24.58 & 312.262 & 3717.727 & 2853.32 & 864.407 & 16.71 \\
\hline & & WBS-B4 & 26.21 & 249.81 & 1763.982 & 1245.199 & 518.783 & 16.65 \\
\hline & & WBS-B5 & 29.1 & 112.414 & 847.98 & 467.431 & 380.549 & 16.32 \\
\hline & \multirow{5}{*}{ WBS-C } & WBS-C1 & 15 & 489.448 & 8239.036 & 6628.04 & 1610.996 & 15.19 \\
\hline & & WBS-C2 & 20 & 435.065 & 5992.43 & 4798.544 & 1193.886 & 15.87 \\
\hline & & WBS-C3 & 23 & 339.895 & 3965.92 & 3043.812 & 922.108 & 16.2 \\
\hline & & WBS-C4 & 26.05 & 271.916 & 1881.75 & 1328.33 & 553.42 & 16.45 \\
\hline & & WBS-C5 & 29.97 & 122.361 & 904.59 & 498.64 & 405.95 & 16.02 \\
\hline
\end{tabular}

\subsection{Models Validation}

The validation of the proposed semi-empirical model to predict swelling stress is as follows: Comparing the predicted values with the experimental values, comparing values obtained from the proposed semi-empirical model with the values obtained from other semi-empirical models developed by [4,6,11]. Figure 23 shows the comparison of the swelling stress experimental values obtained from the Zero-swell test and the results obtained from the predictive model. The scatter plot generally follows the trend line 1:1 with a correlation coefficient of $93.72 \%$. There is a good correlation between the experimental and the predicted values.

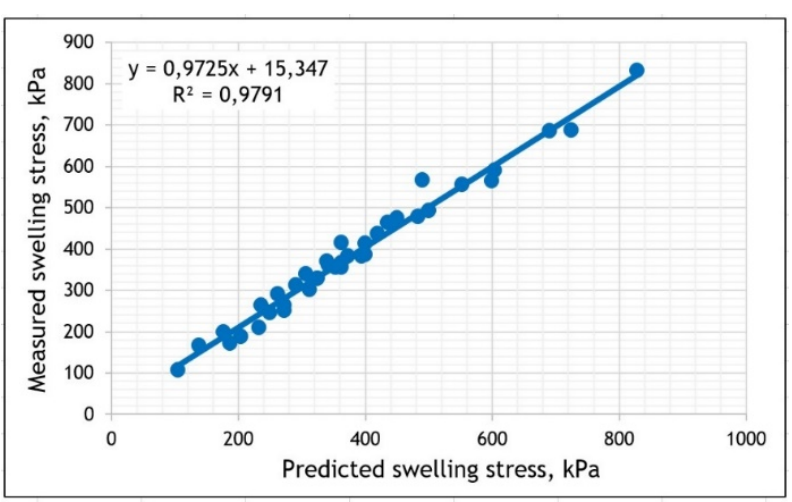

Figure 23. Predicted swelling stress vs Measured swelling stress 
Figure 24 shows a graphical comparison between the predicted values of the swelling stress of the model developed in this research work and the predicted values obtained from the model developed by [4]. The model proposed in this study described a better correlation between the experimental and predictive values of the swelling stress, unlike the formerly model developed by [4] that exhibits a weak correlation coefficient. Besides, the plotted data for the models designed in this research work are very close to the $1: 1$ line. These discrepancies originated from the type of soil material utilized in the experiment. Reference [4] model development is related to the artificial soil made of sodium bentonite and kaolinite. The model proposed in this research work describes the swelling stress of field compacted heaving soils.



Figure 24. Predicted swelling stress vs predictive model by [4]

Figure 25 shows a graphical comparison between the predicted values of the swelling stress of the constitutive model developed in this study and the predictive model proposed by [6]. The model of this research work portrays a better correlation between experimental and predicted values of swelling stress. The plotted data points are close to the 1:1 line, like the model previously proposed by [6]. These similarities originated from the type of soil specimen are used to develop the models. The design of the model developed in this research work as well as the model previously proposed by [6] makes use of field compacted heaving soils.

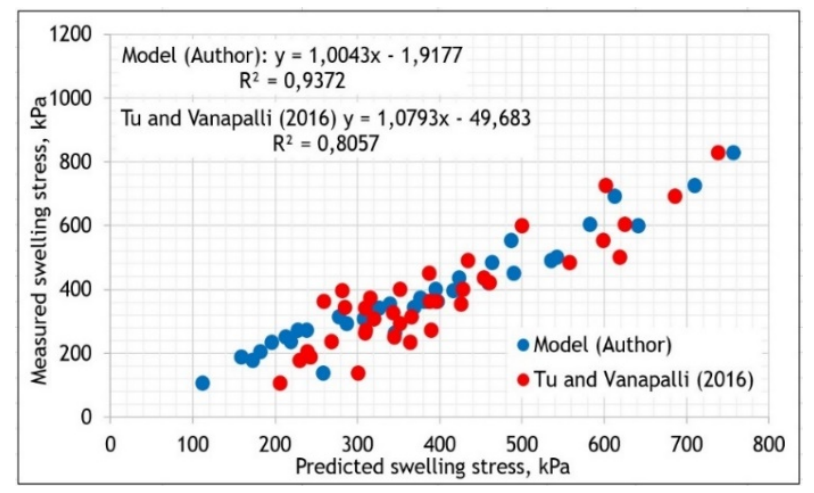

Figure 25. Predicted swelling stress vs predictive model by [6]
Figure 26 presents a graphical comparison between the predicted values of swelling stress from the constitutive model developed in this study and the predictive model proposed by [11]. The model of this research work portrays a better correlation between the experimental and predicted swelling stress values. The plotted data points are close to the 1:1 line. The model proposed by [11] displays a very poor correlation. These discrepancies originated from the non-compacted soil specimens are used to design the model previously proposed by [11]. Also, the model does not consider the suction, a fundamental property of unsaturated heaving soils.

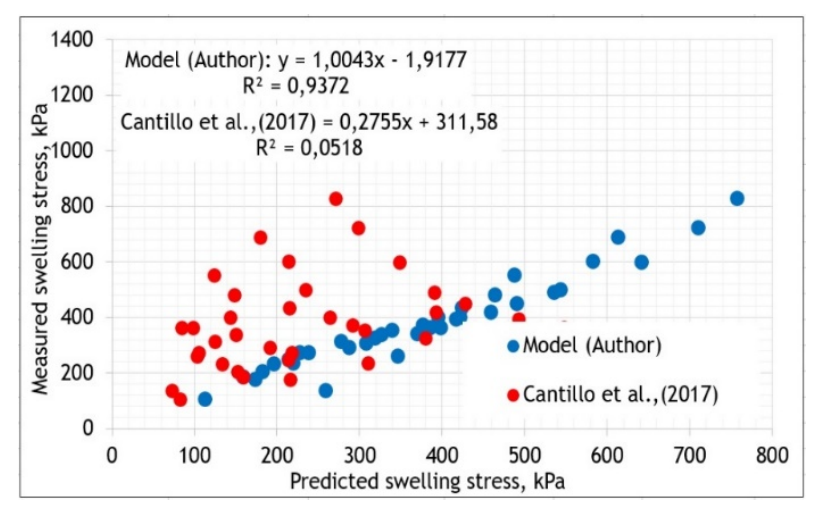

Figure 26. Predicted swelling stress vs predictive model by [11]

In general, a good correlation between the predictive and experimental results confirms that the model proposed in this research work predicts the swelling stress with acceptable accuracy. Besides, the graphical comparison demonstrates a better correlation of the model developed in this research work than the models previously proposed by $[4,11]$. There are some similarities with the results of the model proposed by [6].

\section{Concluding Remarks}

The objective of this research work is to develop a mathematical model to predict the swelling stress of compacted heaving soils. The study revealed that at the OWC, the swelling stress values of compacted heaving soils increase when the matric suction, initial water content, plasticity index, and free swell ratio increase. Nevertheless, the swelling stress value reduces at the OWC when the initial dry unit weight and the linear shrinkage increase upon water addition. The montmorillonite is the predominant clay mineral in the study area and influences significantly the swelling properties of these soils. Soils in the study area develop an upward swelling stress value within the range of 176.88 $\mathrm{kPa}$ to $362.30 \mathrm{kPa}$ at the OWC and explain the damages observed on lightweight constructions. Lastly, the semi-empirical predictive model developed in this research work is found more accurate than other reviewed models. The model can be used to assess the swelling 
stress and enhance the design. The oedometer swelling test is alleviated, and the processing time reduces.

\section{REFERENCES}

[1] Tony Williams, John Terry Pidgeon, Peter William Day, "Expansive soils," Civil Engineering = Siviele Ingenieurswese, vol. 27, no. 7, pp. 367-377, 1985. https://hdl.handle.net/10520/AJA10212019 15544 ( accessed Sept. 23, 2020).

[2] Richard Driscoll, Mike Crilly, "Subsidence Damage to Domestic Buildings: Lessons Learned and Questions Remaining," CRC, 2000. London, UK.

[3] John Nelson, Deborah Miller, "Expansive Soils: Problems and Practice in Foundation and Pavement Engineering," John Wiley \& Sons, 1997. USA.

[4] Erzin Yusuf, Erol Orhan, "Swell Pressure Prediction by Suction Methods," Engineering Geology, vol. 92, no 3-4, pp. 133-145, 2007. DOI: 10.1016/j.enggeo.2007.04.002.

[5] Adejumo Taiye Elisha, "Prediction of Swell Pressure of Black Cotton Soil of North-Eastern Nigeria," Electronic Journal of Geotechnical Engineering, vol. 17, pp. 1731-1739, 2012. http://www.ejge.com/2012/Ppr12.142alr.pdf (accessed Nov. 08, 2020).

[6] Hongyu Tu, Sai K. Vanapalli, "Prediction of the Variation of Swelling Pressure and One-Dimensional Heave of Expansive Soils with Respect to Suction Using the Soil-Water Retention Curve as a Tool," Canadian Geotechnical Journal, vol. 53, no 8, pp. 1213-1234, 2016, DOI: $10.1139 /$ cgj-2015-0222.

[7] Jahanzaib Israr, Khalid Farooq, Hassan Mujtaba, "Modelling of Swelling Parameters and Associated Characteristics Based on Index Properties of Expansive Soils," Pakistan Journal of Engineering \& Applied Sciences, vol. 15, pp. 1-9, 2014.

https://journal.uet.edu.pk/ojs_old/index.php/pjeas/article/vi ew/89/50 (accessed Sept. 23, 2020).

[8] Asuri Sridharan, K. Prakash, "Classification Procedures for Expansive Soils," Proceedings of the Institution of Civil Engineers-Geotechnical Engineering, Vol.143, No. 4, pp. 235-240, 2000. DOI: 10.1680/geng.2000.143.4.235.

[9] Tan YA, "Swelling pressure and retaining wall design in expansive Soils," Master of Science Thesis, 2016. RMIT University, Melbourne.

[10] Amir Jaleh Forouzan, "Prediction of Swelling Behaviour of Expansive Soils Using Modified Free Swell Index, Methylene Blue and Swell Oedometer Tests," Master of Science Thesis, 2016. Middle East Technical University.

[11] Victor Cantillo, Vicente Mercado, César Pájaro, "Empirical Correlations for the Swelling Pressure of Expansive Clays in the City of Barranquilla," Colombia Earth Sciences Research Journal, vol. 21, no.1, pp. 45-49, 2017. DOI: 10.15446/esrj.v21n1.60226.

[12] Charles Lucian, "Geotechnical Aspect of Building on Expansive Soils in Kibaha, Tanzania: Preliminary Study,"
Licenciate Thesis, Royal Institute of Technology, 2006. Stockhlom, Sweden.

[13] ASTM, "Standard Test Method for Particle-Size Distribution (Gradation) of Soils Using Sieve Analysis," D 6913; 04. 09, American Society for Testing and Materials, PA, USA, 2009. DOI: 10.1520/d6913-04r09.

[14] ASTM, "Standard Test Method for Particle-size Distribution (Gradation) of Fine-Grained Soils Using the Sedimentation (Hydrometer) Analysis," D 7928; 04. 09, American Society for Testing and Materials, PA, USA, 2016. DOI: $10.1520 / \mathrm{d} 7928-16 \mathrm{e} 01$.

[15] ASTM, "Standard Test Method for Liquid Limit, Plastic Limit, and Plasticity Index of Soils," D 4318; 04. 08, American Society for Testing and Materials, PA, USA, 2005. DOI: $10.1520 / \mathrm{d} 4318-17 \mathrm{e} 01$.

[16] ASTM, "Standard Test Method for the Specific Gravity of Soils," D 854; 04. 08, American Society for Testing and Materials, PA, USA, 2014. DOI: 10.1520/d0854-14.

[17] TMH1-A4, "The Determination of the Linear Shrinkage of Soils," Council for Scientific and Industrial Research, Pretoria, South Africa, 1986. http://asphalt.csir.co.za/tmh/a 4.pdf (accessed sept.3, 2020).

[18] SABS, "Civil Engineering Test Methods, Determination of the Maximum Dry Density and Optimum Moisture Content," SANS 3001, Part GR30, South Africa Bureau of Standards, Pretoria, 2016.

[19] ASTM, "Standard Test Method for One-Dimensional Swell or Collapse of Soils," D 4546; 04 .08, American Society for Testing and Materials, PA, USA, 2014. DOI: $10.1520 / \mathrm{d} 4546-14 \mathrm{e} 01$.

[20] ASTM, "Standard Test Method for Measurement of Soil potential (Suction) using filter paper," D 5298; 04. 08, American Society for Testing and Materials, PA, USA, 2016. DOI: 10.1520/d5298-16.

[21] Adnan A. Basma, Azm S. Al-Homoud, Abdallah Husein Malkawi, "Laboratory Assessment of Swelling Pressure of Expansive Soils," Applied Clay Science, vol. 9, no. 5, pp. 355-368, 1995. DOI: 10.1016/0169-1317(94)00032-L.

[22] Attom Mousa Fattom, Samer Barakat, "Investigation of Three Methods for Evaluating Swelling Pressure of Soils," Environmental \& Engineering Geoscience, vol. 6, no. 3, pp. 293-299, 2000. http://worldcat.org/issn/10787275 (accessed sept. 23, 2020).

[23] Richard Johnson, Irwin Miller, John Freund, "Miller and Freund's Probability and Statistics for Engineers," Seventh Edition, Prentice Hall, 2005. New Jersey, USA.

[24] Ebrahim Asghari Kaljahi, Ghodrat Barzegari, Shahrokh jalali-Milani "Assessment of the Swelling Potential of Baghmisheh Marls in Tabriz, Iran," Geomechanics and Engineering, vol. 18, no. 3, pp. 267-275, 2019. DOI: 10.12989/gae.2019.18.3.267.

[25] Srirama Rao, Phanikumar Bhyravajjula, Radhey S. Sharma, "Prediction of Swelling Characteristics of Remoulded and Compacted Expansive Soils Using Free Swell Index," Quarterly Journal of Engineering Geology \& Hydrogeology, vol. 37, no. 3, pp. 217-226, 2004. DOI: 10.1144/1470-9236/03-052. 
[26] Emilia Wójcik, Ireneusz Gawriuczenkow, "Determination of Swell Index and Swelling Pressure from Suction Tests- a Case Study of Neogene Clays from Warsaw (Poland), "Geotechnical Quaterly, vol. 61, no. 4, pp. 738 -750, 2017. DOI: $10.7306 /$ gq. 1362 .

[27] Rank Kinjal, Mehta Jintendra, Bhandari Jaydeep, "Swelling Potential of Different Expansive Soil Placed at Different Dry Density and Initial Water Content by Constant Volume
Method," International Journal of Innovative Research in Science, Engineering and Technology, vol. 7, no. 3, 2018. DOI: 10.15680/ijirset.2018.0703016.

[28] Armand Augustin Fondjo, Elizabeth Theron, "Assessment of the Mineral Composition of Heaving Soils Using Geotechnical Properties," Civil Engineering and Architecture, vol. 8, no. 4, pp. 619 - 631, 2020. DOI: 10.13189/cea.2020.080425. 